\title{
Sloshing Simulation OF a Tank Oscillating Towards Multiple Degrees of Freedom by Particle Method
}

\author{
Shigeyuki Hibi ${ }^{1}$; Kazuki Yabushita \\ National Defense Academy, Department of Mechanical Systems Engineering, \\ 1-10-20 Hashirimizu, Yokosuka, Kanagawa, 239-8686, Japan \\ e-mail: ${ }^{1}$ hibiteru@nda.ac.jp
}

\begin{abstract}
The tank sloshing problem is very important at design time in LNG/LPG ships. This problem causes impulsive loads to ship structures and is often treated as a non-linear one. In order to estimate these impulsive loads, properly many studies have been carried out through both experimental and numerical approaches. Impulsive pressure on the wall of a tank induced by forced multi-degree oscillations is focused in this research. It is shown in the past authors' experiment that forced multi-degree oscillations cause stronger impulsive pressure as compared to individual oscillations. Numerical analysis by a particle method based on finite volume technique is introduced in this study to simulate the above phenomena. The suggested particle method is shown to be useful for simulating a strong nonlinear phenomenon. The authors discuss the calculated results of pressure time history with the experimental results.
\end{abstract}

\section{Keywords}

Sloshing; Impulsive load and pressure; Particle method; Finite volume method.

\section{Introduction}

Sloshing is a phenomenon in which a liquid surface fluctuates violently when a tank with a free surface is shaken at a cycle close to the natural period of the tank. Large impulsive loads may be applied to walls of the tank at this time. In LNG/LPG ships sailing through irregular waves, large impulsive pressure may be generated on the wall near ceiling area when liquid cargo collides to walls of a cargo tank. Then it is important to know the fluctuating pressure caused by sloshing when considering the strength of tank as a structural member in ship design.

On the other hand, it is known that a ship navigating through waves has a coupled motion of two degrees of freedom and three degrees of freedom, called longitudinal motion and lateral motion, respectively. For this reason, the hull will fluctuate with a phase difference in some axial direction or rotation direction to those axes. As a result, it is possible that larger sloshing may be caused in tanks inside the ship.

In the previous study [1] an apparatus which can oscillate a tank by force was introduced in order to investigate impulsive pressure on the wall of the tank. This apparatus can oscillate it simultaneously towards 3 degrees of freedom (up-down, left-right and rotation) with each phase differences. Through the experiments it was shown larger impulsive pressure could be excited under oscillating the tank simultaneously towards multiple degrees of freedom than under single direction oscillation and the specific phase differences to appear the largest peak values of pressure was identified.

In this study the authors verified the results of above experiments by numerical simulation. The authors have developed a particle method [2] with finite volume technique in order to 
stably simulate a fluid phenomenon with strong nonlinearity such as sloshing. At first static pressure in a tank was verified with the particle method varying the particle number. Next by comparing the time history of pressure with the experiment result of previous study, the effectiveness of the proposed particle method was assured.

\section{Numerical Analysis Based on Particle Method with Finite Volume Technique}

In particle methods, fluid is modeled as a collection of particles and discretized by considering the interaction between particles without a calculation lattice. Therefore, particle methods are suitable for intense fluid analysis with strong nonlinearity. Here, we explain the outline of the particle method proposed by us with finite volume techniques.

The fundamental equations described by a fluid particle coordinates $\hat{r}$ are represented by the Navier-Stokes equations and the continuous equation.

$$
\begin{gathered}
\left.\frac{\partial \boldsymbol{v}}{\partial t}\right|_{\hat{r}}=-\frac{1}{\rho} \hat{\nabla} p+\boldsymbol{K}+\nu \hat{\nabla} \cdot \hat{\nabla} \boldsymbol{v} \\
\hat{\nabla} \cdot \hat{\nabla} p=\rho \lim _{\Delta \rightarrow 0} \frac{\hat{\nabla}(t, \hat{r}) \cdot \boldsymbol{v}(t-\Delta t, \hat{r}-\Delta \hat{r})}{\Delta t}
\end{gathered}
$$

Here $\boldsymbol{v}$ is the speed of particles, $p$ is the pressure of particles, $\rho$ is the density of fluid, $\boldsymbol{K}$ is outer forces and $v$ is the kinematic coefficient of viscocity of fluid. From Gauss's theorem equations (1) and (2) are transformed into flow equations of integral shape.

$$
\begin{aligned}
& \left.\frac{\partial \boldsymbol{v}}{\partial t}\right|_{\hat{r}}=-\lim _{V \rightarrow 0} \frac{1}{\rho V} \int_{S} p \boldsymbol{n} d S+\boldsymbol{K}+\lim _{V \rightarrow 0} \frac{\nu}{V} \int_{S} \frac{\partial \boldsymbol{v}}{\partial n} d S \\
& \lim _{V \rightarrow 0} \frac{1}{V} \int_{S} \frac{\partial p}{\partial n} d S=\lim _{\substack{\Delta t \rightarrow 0 \\
V \rightarrow 0}} \frac{\rho}{V \Delta t} \int_{S} \boldsymbol{v}(t-\Delta t) \cdot \boldsymbol{n} d S
\end{aligned}
$$

Here $\boldsymbol{n}$ is the normal vector of a particle and $\boldsymbol{V}$ is the volume of a particle.

Eventually, the discretized equations are derived from equations (3) and (4) in the proposed method.

$$
\begin{aligned}
\frac{v_{i}-v_{i}^{n-1}}{\Delta t}= & -\frac{1}{\rho \pi R^{2}} \sum_{\substack{j=1 \\
i \neq j}}^{N}\left(P_{i}+\left(P_{j}-P_{i}\right) \frac{R}{r_{i j}}\right) n_{i j} \Delta S_{i j}+\boldsymbol{K}+\frac{\nu}{\pi R^{2}} \sum_{\substack{j=1 \\
i \neq j}}^{N} \frac{v_{j}-v_{i}}{r_{i j}} \Delta S_{i j} \\
& \sum_{\substack{i=1 \\
i \neq j}}^{N} \frac{P_{j}-P_{i}}{r_{i j}} \Delta S_{i j}-\frac{P_{i}}{R}\left(2 \pi R-S_{i}\right) \\
= & \frac{\rho}{\Delta t}\left(\sum_{\substack{i \neq 1 \\
i \neq j}}^{N}\left(v_{i}^{n-1}+\left(v_{j}^{n-1}-\boldsymbol{v}_{i}^{n-1}\right) \frac{R}{r_{i j}}\right) \cdot n_{i j} \Delta S_{i j}-v_{i}^{n-1} \cdot S_{i}\right)
\end{aligned}
$$

Here

$$
\begin{aligned}
\boldsymbol{r}_{\boldsymbol{i}} & =\left(x_{i}, y_{i}\right) \\
\boldsymbol{r}_{i j} & =\boldsymbol{r}_{\boldsymbol{j}}-\boldsymbol{r}_{\boldsymbol{i}} \\
r_{i j} & =\sqrt{\left(x_{j}-x_{i}\right)^{2}+\left(y_{j}-y_{i}\right)^{2}} \\
\boldsymbol{n}_{\boldsymbol{i j}} & =\frac{\boldsymbol{r}_{\boldsymbol{i j}}}{r_{i j}}
\end{aligned}
$$




$$
\begin{aligned}
& \Delta S_{i j}=2 \alpha R^{2}\left(1-\cos \theta_{i j}\right) \\
& \alpha=\frac{2}{\sum_{j=1, j \neq i}^{N}\left(1-\cos \theta_{i j}\right)} \\
& S_{i}=\sum_{j=1, j \neq i}^{N} n_{i j} \Delta S_{i j}, S_{i}=\sum_{j=1, j \neq i}^{N} \Delta S_{i j} \\
& \boldsymbol{K}=(0,-g) \\
& \theta_{i j}= \begin{cases}\cos ^{-1} \frac{r_{i j}}{r_{R}} & \left(r_{i j}<\sqrt{2} R\right) \\
\sin ^{-1} \frac{R}{r_{i j}} & \left(\sqrt{2} R \leq r_{i j}\right)\end{cases}
\end{aligned}
$$

Subscript $i$ means the particle number of interest and subscript $j$ means the neighboring particle number of the particle $i$. Superscript $n$ indicates the time step number.

$\boldsymbol{r}_{i}$ means position vector of the $i$-th particle. The particles are assumed to be spherical (in 2D model just round) and the influence of the neighboring particle $j$ to the particle $i$ is carried out through the micro surface area $\Delta S_{i j}$ expressed by equation (7) according to the concept of the Finite Volume Method.

$R$ stands for the radius of a particle and satisfies the following equation.

$$
\pi R^{2}=D^{2}
$$

$D$ is the average inter-particle distance and is determined by the spatial resolution of the calculation model. This parameter corresponds to the smoothing length $\mathrm{h}$ in the SPH[3].

Considering the efficiency and stability of calculation, it is considered that neighboring particles far from the so called influence radius $r_{e}$ do not affect. In this study the following vallue is adopted for the parameter $r_{e}$.

$$
r_{e}=3.1 \mathrm{D}
$$

The pressure value of particles at each time step is obtained by implicitely solving the equation (6) using the PCGS method The velocity value of particles is also obtained from the equation (5) implicitly using the PCGS method in case of considering viscosity of fluid and explicitly in case that viscosity is not taken into consideration.

\section{Experimental Apparatus and Condition}

\subsection{Specification of Oscillation Apparatus}

The apparatus used in this study can oscillate a tank attached on the bracket harmonically and simultaneously towards 3 degrees of freedom with each phase differences (See Fig. 1 and Table 1).

The size of tank is 400, 400, 100 (mm) (Height, Width, Depth). We define the symbols for the oscillation directions of 3 degrees of freedom as follows in Fig. 2. Heave oscillation (Up down) stands for $\mathrm{Z}$ and Sway oscillation (Left - right) stands for $\mathrm{X}$ and Roll oscillation (Rotation) stands for $\theta$.

A pressure sensor is attached on the right side of the tank mounted on the apparatus. The position of the sensor is $40 \mathrm{~mm}$ from the bottom. The pressure receiver has round area with diameter of $8 \mathrm{~mm}$. 


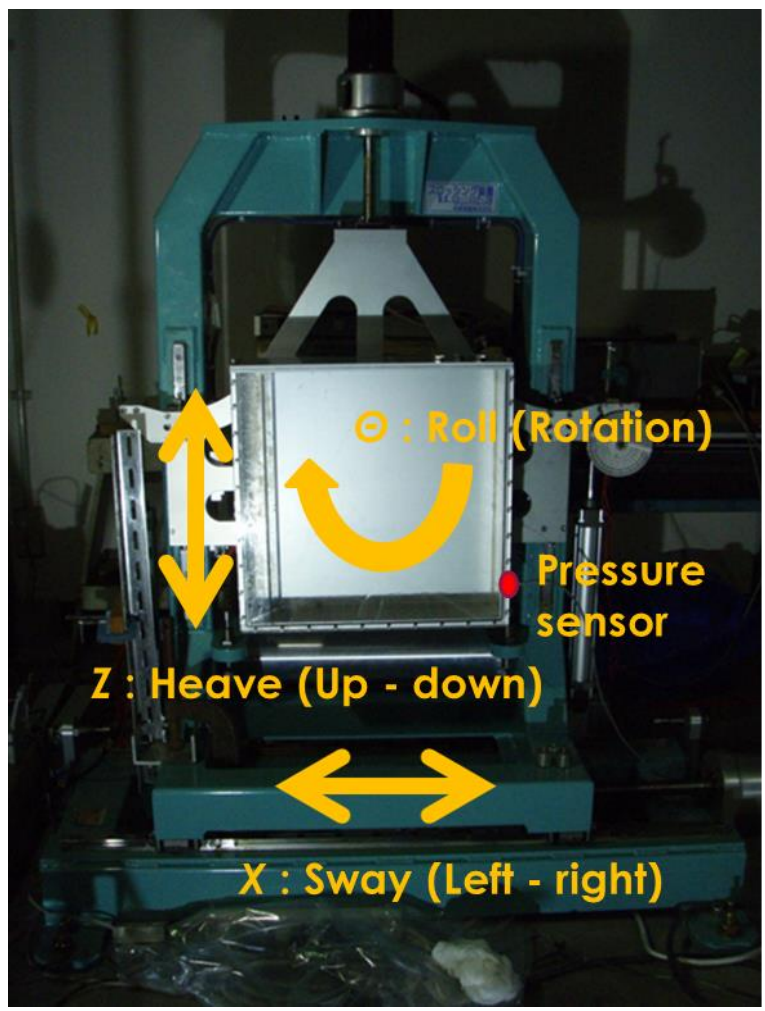

Fig. 1: Oscillation apparatus with 3 degrees of freedom

Tab. 1: Specification of the apparatus about oscillation

\begin{tabular}{|l|c|c|}
\hline Direction of oscillation & Maximum amplitude & Minimum period \\
\hline Heave (Z) (Up-down) & $\pm 50 \mathrm{~mm}$ & $1.0 \mathrm{sec}$. \\
\hline Sway (X) (Left-right) & $\pm 50 \mathrm{~mm}$ & $1.0 \mathrm{sec}$. \\
\hline Roll $(\theta)$ (rotation) & $\pm 45 \mathrm{deg}$. & $1.0 \mathrm{sec}$. \\
\hline
\end{tabular}

\subsection{Selection of Phase Differences during Simultaneous Oscillation towards 2 Degrees of Freedom}

In previous study [1] we chose 3 pairs of 2 degrees of freedom from 3 ones. Those will be subscribed as follows $(\theta-X, \theta-Z, X-Z)$. The oscillation period is uniformly $1.08 \mathrm{sec}$. which is close to the natural period of the tank in case of the water depth is $60 \mathrm{~mm}$ (fixed). The oscillation amplitudes are $15 \mathrm{~mm}$ for $X$ and $Z$ and 20 degrees for $\theta$.

We measured time histories of pressure on the wall of the tank repeatedly while changing the phase difference from 0 degree to 360 degrees. We identified the phase difference which cause the largest peak value of pressure for each oscillation pair $(\theta-X, \theta-Z, X-Z)$. The results are shown in Table 2.

Tab. 2: Phase difference which cause the largest peak value

\begin{tabular}{|l|r|}
\hline Oscillation pair & Phase difference \\
\hline$\theta-X$ & 15 degrees \\
\hline$\theta-Z$ & 335 degrees \\
\hline$X-Z$ & 220 degrees \\
\hline
\end{tabular}




\subsection{Comparison of Calculation Accuracy of the Particle Method with Static Pressure}

At first we confirm accuracy of the proposed particle method by static pressure. In Fig. 2 a tank model used in the above experiment is shown. Water depth is $60 \mathrm{~mm}$ as in the experiment. The total particle number is 3,700 . The average inter-particle distance D is 38 $\mathrm{mm}$. We define this model of spatial resolution as the base model and name it X1 model. In addition to this model we prepare 3 additional models named $\mathrm{X}_{1 / 2}$ (1,500 particles), $\mathrm{X} 2$ (10,500 particles), X4 (33,700 particles) model of which D is half, double and 4 times each other.

Numerical simulation was carried out with the time step of $0.0001 \mathrm{sec}$. in all cases. Fig. 3 shows the time history of static pressure at the bottom of tank. In all calculation models we can see some fluctuations for the first few seconds in simulation time and after that the pressure values become fairly stable. These fluctuations of pressure occur when relative position of particles turns more stable and closer from the initial particle arrangement in a tetragonal lattice.

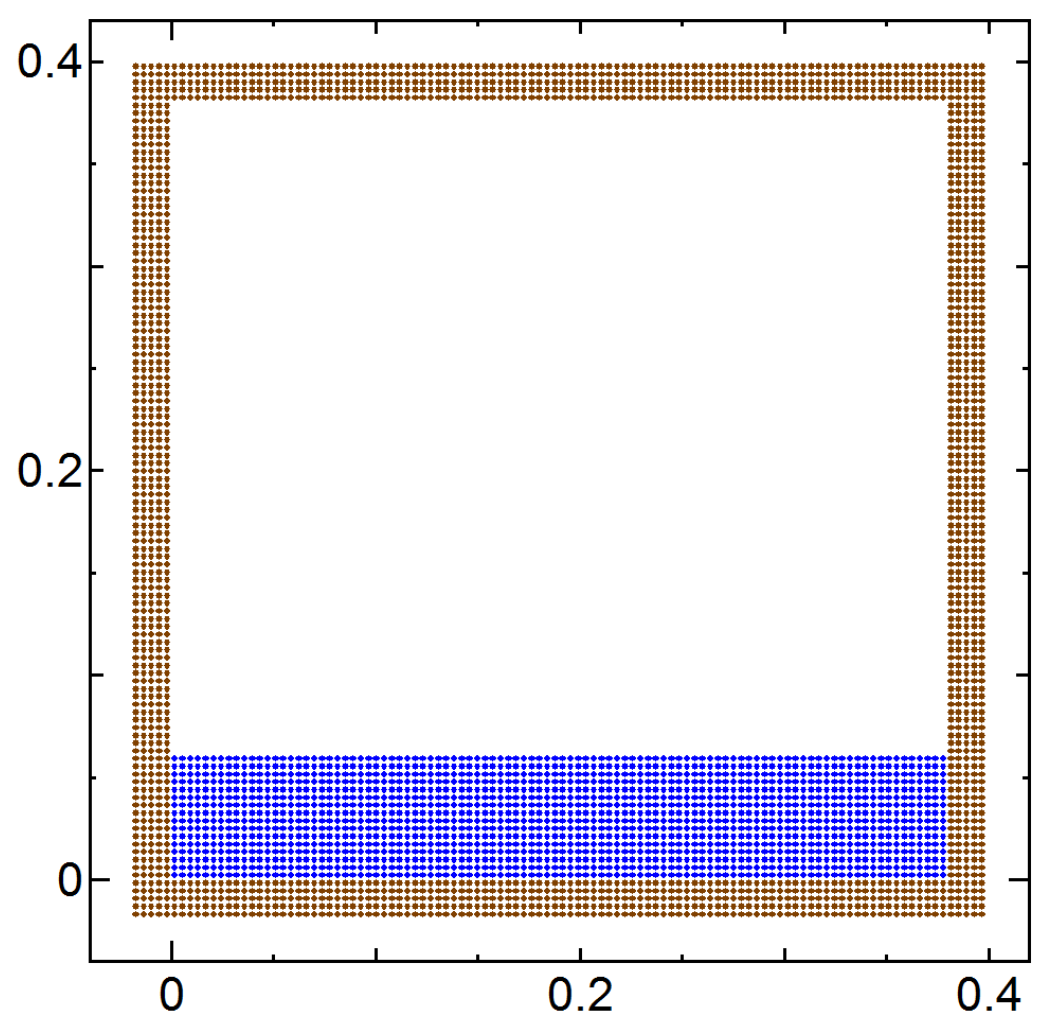

Fig. 2: Initial particle arrangement for static pressure

Table 2 shows Comparison of static pressure with the theoretical value. It can be seen that the calculation accuracy is improved according to the spatial resolution.

Tab. 3: Comparison of static pressure with the theoretical value

\begin{tabular}{|l|c|c|}
\hline & Simulation result (Pa) & Error (\%) \\
\hline X1 & 616 & 3.36 \\
\hline X2 & 610 & 2.35 \\
\hline X4 & 607 & 1.85 \\
\hline
\end{tabular}




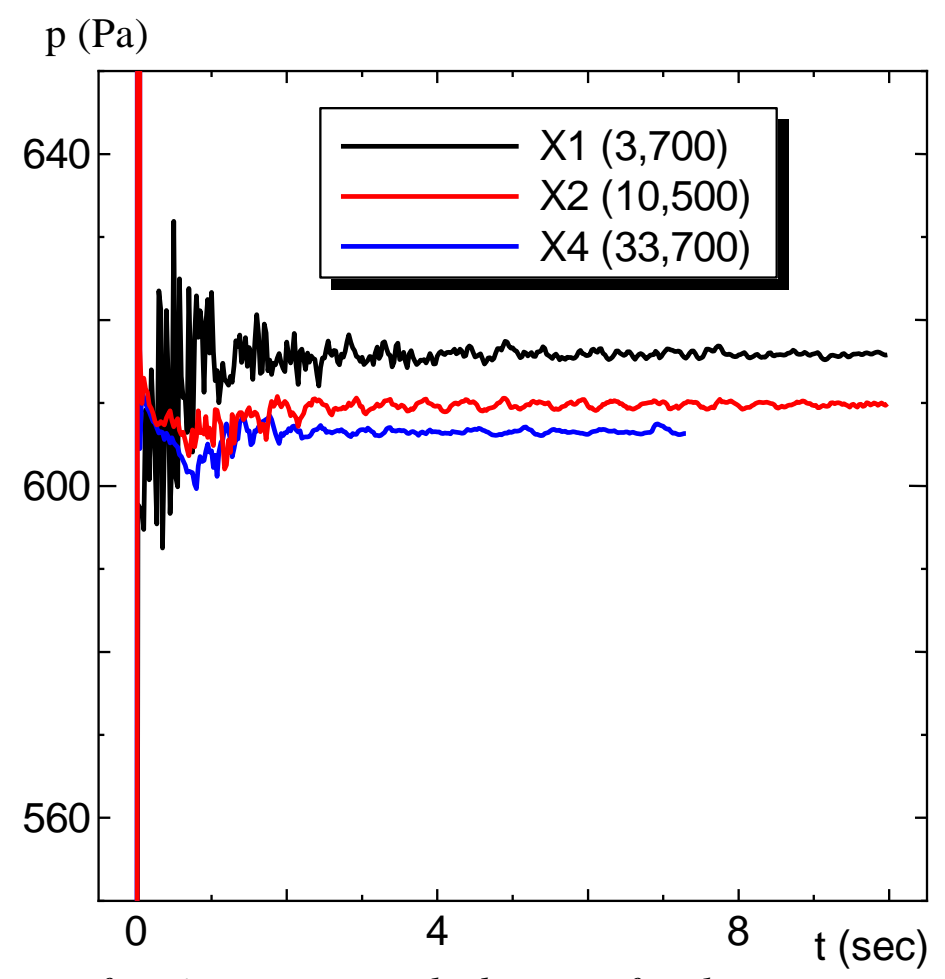

Fig. 3: Time history of static pressure at the bottom of tank

\subsection{Numerical Simulation of Forced Oscillation towards 2 Degrees of Freedom}

Numerical simulation was carried out under the same conditions as experiment obtained in Section 3.2. Fig. 4 (a) to Fig. 4 (d) show comparison of the experiment and simulation results for time history of pressure value at the position where the pressure sensor is attached. The experimental values are results obtained through a $100 \mathrm{~Hz}$ low-pass filter and the accuracy of those results are evaluated by a FFT analysis and statistical approaches in the previous paper [1].

From these results, it can be seen that the numerical results have good agreement with the experiment for each models where pressure peaks are observed. But at the time when the pressure sensor is exposed by forced oscillation as shown in Fig. 6 (a) and (b), the pressure values by numerical simulation are 0 in any models, whereas the experiment results show significant values which is not 0 . The reason for this is due to viscosity and surface tension in actual water. Even if the pressure sensor is exposed, actually some water is traveling on the wall surface or some water remains on the sensor because of surface tension. However the current proposed particle method does not consider these effects. 


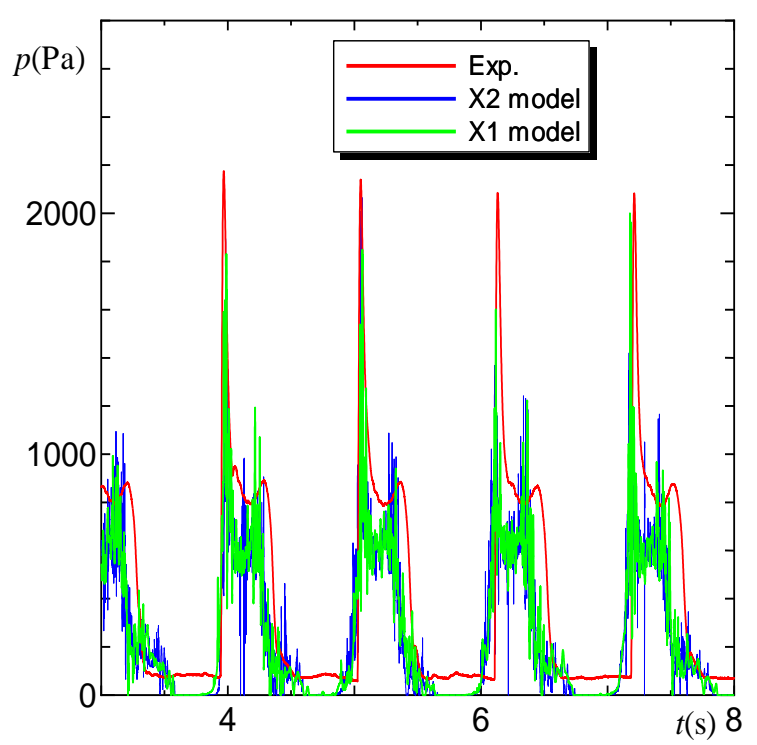

Fig. 4 (a): Time history about $\theta-X$ oscillation.

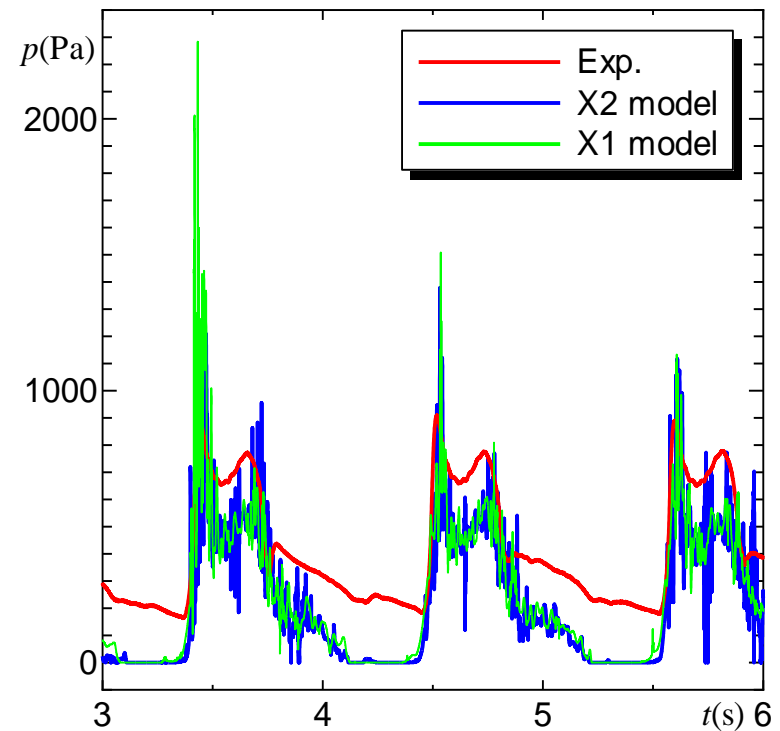

Fig. 4 (c): Time history about $X-Z$ oscillation

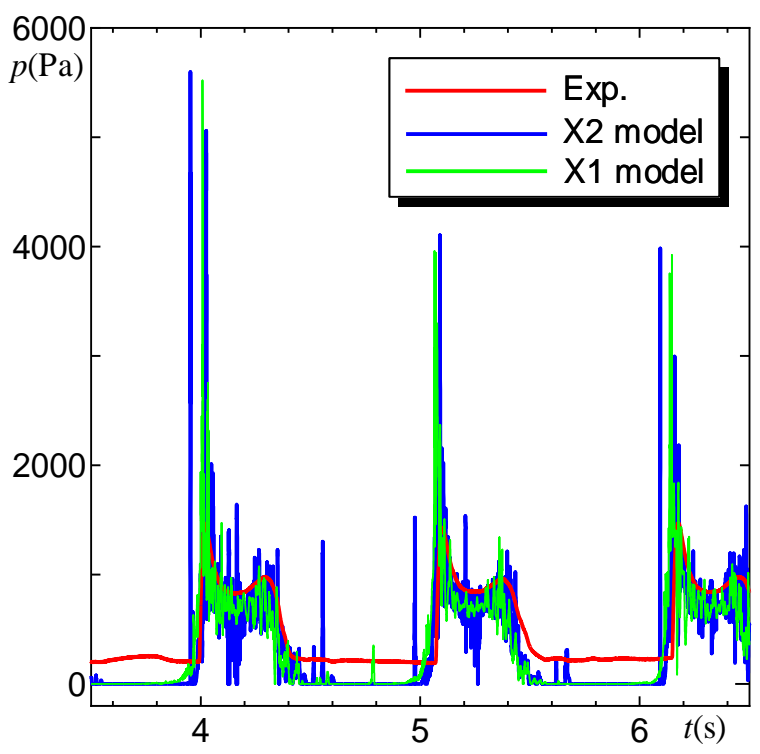

Fig. 4 (b): Time history about $\theta-Z$ oscillation.

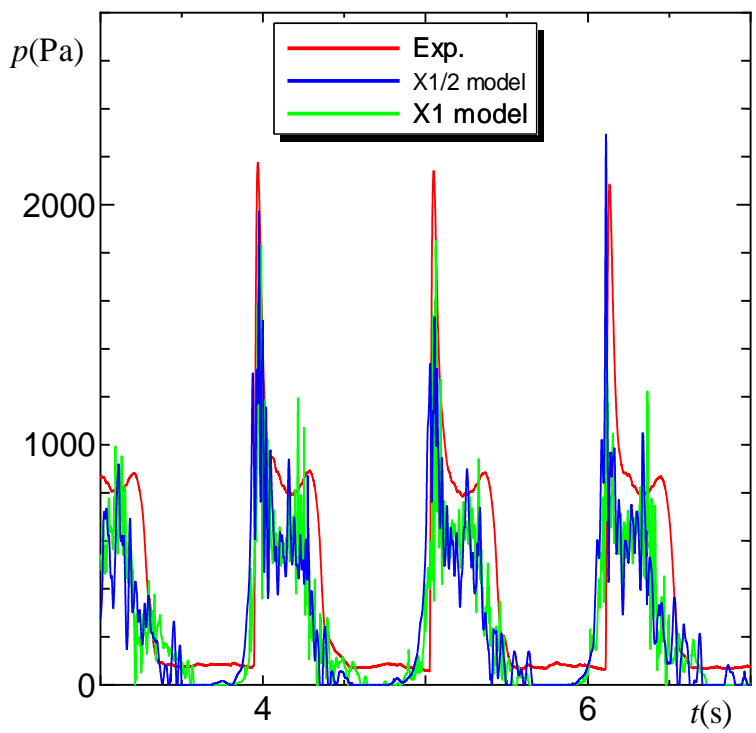

Fig. $4(d)$ : Time history about $\theta-X$ oscillation.

Although the peak period and peak value shown in Figures are almost reproduced, the simulation results show that the pressure values are evaluated to a smaller value as compared with the experimental values in all models. One reason for this is that relatively low peak values are considered to be difficult to stand due to numerical viscosity. Another reason is believed to be due to the relation between the area of the pressure sensor and the special resolution in the simulation. While the diameter of the pressure sensor is $8 \mathrm{~mm}$, the average inter-particle distance $D$ is $38 \mathrm{~mm}$ in the $\mathrm{X} 1$ model and $19 \mathrm{~mm}$ in the $\mathrm{X} 2$ model. Further study will be needed for this problem. 


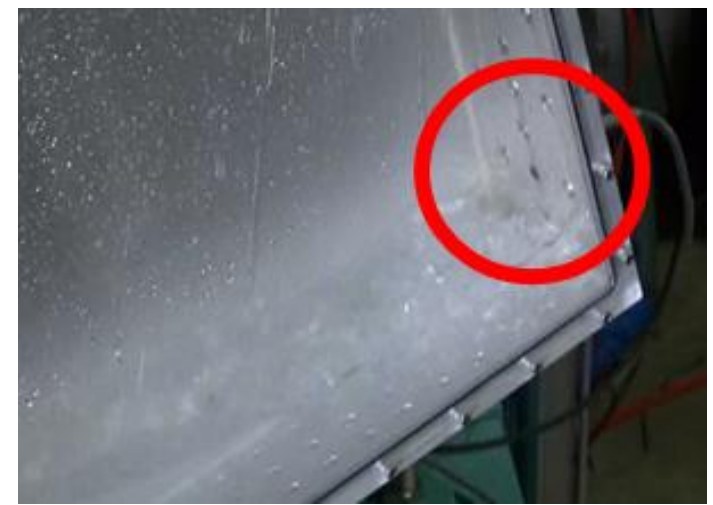

Fig. 5 (a): Moment of exposure of the pressure sensor about $\theta-X$ oscillation.

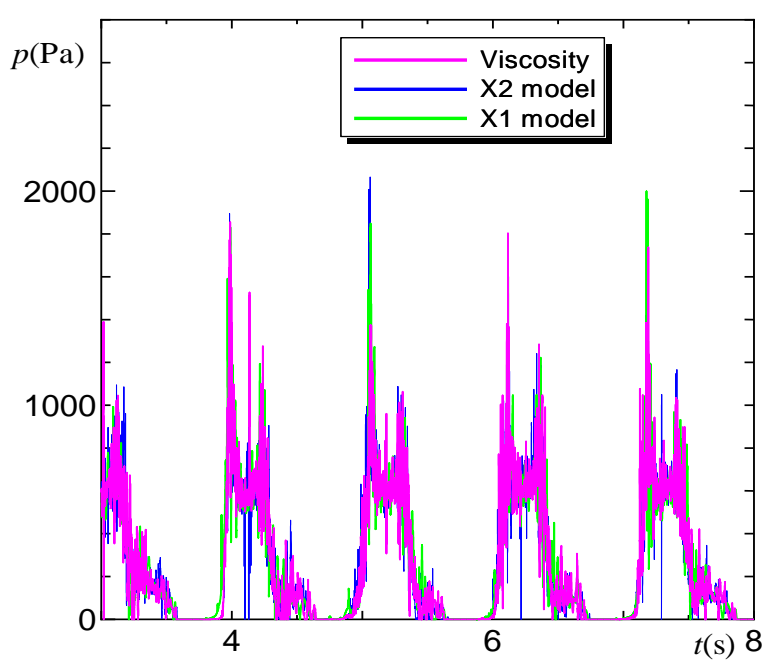

Fig. 6 (a): Time history about $\theta-X$ oscillation.

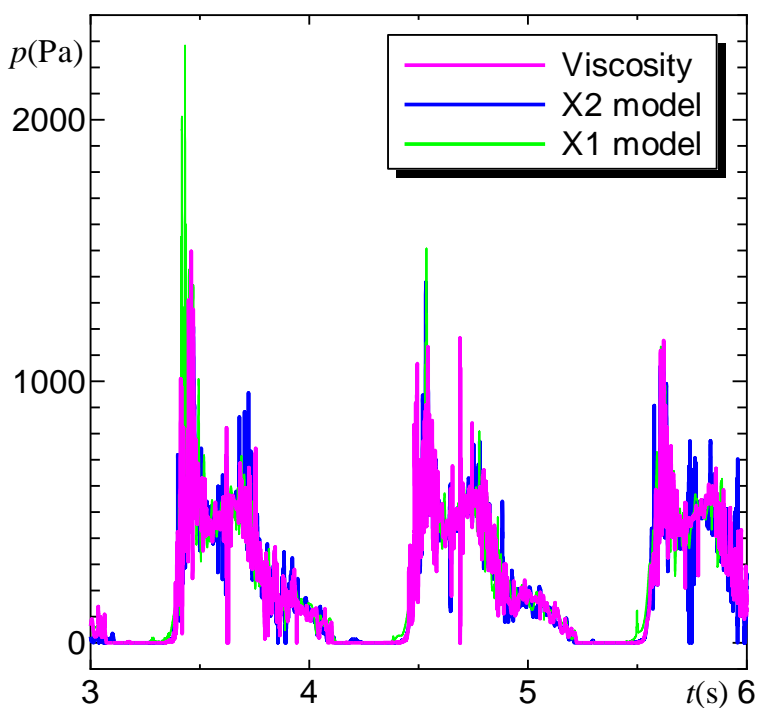

Fig. 6 (c): Time history about $Z-X$ oscillation.

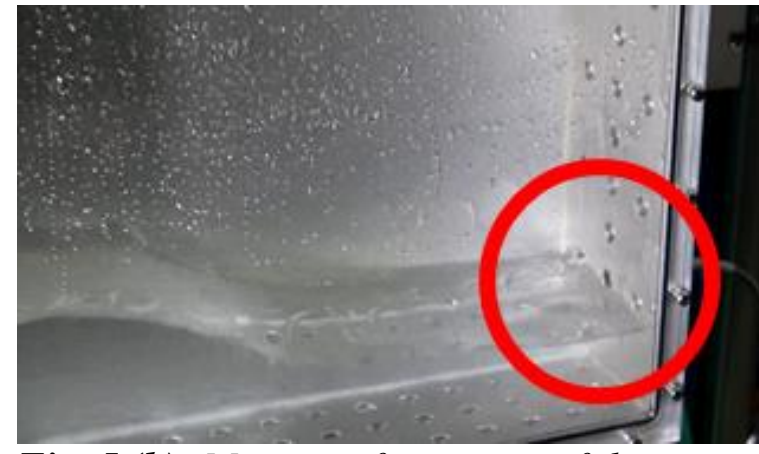

Fig. 5 (b): Moment of exposure of the pressure sensor about $X-Z$ oscillation.

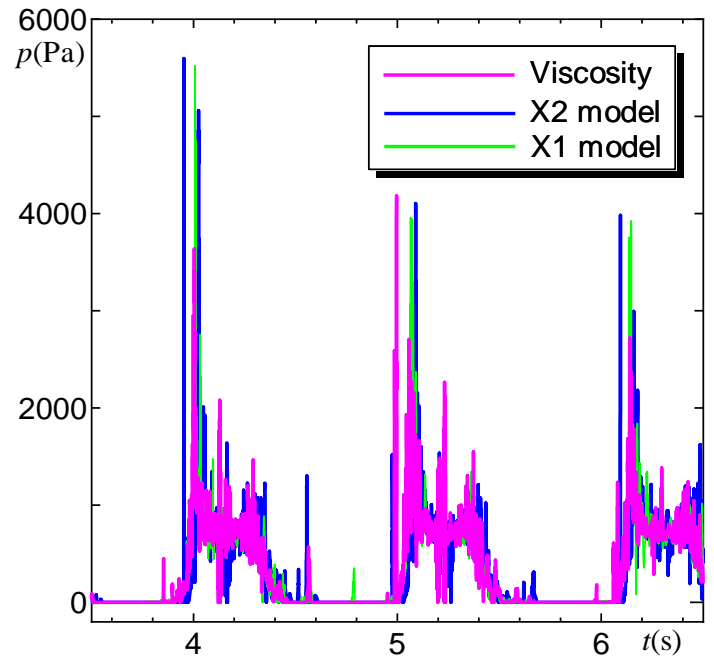

Fig. 6 (b): Time history about $\theta-Z$ oscillation. 
In Fig. 4 (d) the numerical result added for the X1/2 model about $\theta-X$ is shown. Evenif the number of particles is just 1,500, it is observed that the accuracy of the analysis is similar. This shows the superiority of the proposed particle method.

Fig. 6 (a) to Fig. 6 (c) show comparison of the experiment and simulation results considering fluid viscorsity for time history of pressure value at the position where the pressure sensor is attached.

From these results, it can be seen that there certainly is a tendency that the pressure fluctuation becomes looser, such as peak values but even in the case of considering the influence of the fluid viscosity, there is no big change in the overall pressure fluctuation. This implies that influence of the fluid viscorsity is limited in the simulation of intense flows like this study's experiment even though explicitly taking into consideration and the surface tension and wettability by that may be much more .important for pressure fluctuation.

\section{Conclusion}

In this study the authors carried out numerical simulation of forced oscillation towards 2 degrees of freedom and compared with the previous experimental results. Some considerations were found about it as below.

- Effectiveness of the proposed particle method is shown through the numerical simulation of intense sloshing phenomena.

- In addition to the shape of the pressure sensor, the viscosity of water and the surface tension on the wall of tank are considered to be related to the pressure fluctuation.

\section{Literature}

[1] HIBI, S.: Study on the impulsive pressure of tank oscillating by force towards multiple degrees of freedom. EPJ Web of Conferences. 2018, Vol. 180, Paper No. 02034. DOI: $10.1051 /$ epjconf/201818002034

[2] YABUSHITA, K.; HIBI, S: to be posted. Journal of Marine Science and Technology.

[3] MONAGHAN, J. J.: Simulating Free Surface Flows with SPH. Journal of Computational Physics. 1994, Vol. 110, Issue 2, pp. 399-406.

Shigeyuki Hibi; Kazuki Yabushita 


\section{ČÁSTIC}

Problém nárazu nádrže je velmi důležitý ve fázi navrhování lodí LNG / LPG. Tento problém způsobuje impulzní zatížení lodních struktur a často je považován za nelineární. Za účelem správného odhadu těchto impulsních zatížení bylo provedeno mnoho studií jak pomocí experimentálních, tak i numerických přístupů. Tento výzkum se soustřed'uje na impulsní tlak na stěnu nádrže vyvolaný nucenými vícestupňovými oscilacemi. V předchozím experimentu se ukázalo, že nucené vícestupňové oscilace způsobují silnější impulzivní tlak ve srovnání $\mathrm{s}$ jednotlivými oscilacemi. $\mathrm{V}$ této studii je popsána numerická analýza metodou částic založená na technice konečných objemů pro simulaci výše uvedených jevů. Navrhovaná metoda částic se zdá být užitečná pro simulaci silného nelineárního jevu. Autoři srovnávají vypočtené výsledky časové historie tlaku s experimentálními výsledky.

\section{SiMULATION DES PläTSCHERNS DES TANKS ZU EINER MEHRSTUFIGEN SCHWINGUNG DES SPIELRAUMS MIT DER TEILCHENMETHODE}

Das Problem des Anstoßes des Tanks ist in der Phase des Entwurfs von LNG/ LPG-Schiffen sehr wichtig. Dieses Problem verursacht eine impulsartige Belastung der Schiffsstruktur und wird oft als nichtlinear betrachtet. Zum Zweck der richtigen Schätzung dieser impulsartigen Belastungen wurden viele Studien sowohl mit Hilfe von experimentellen als auch numerischen Ansätzen durchgeführt. Diese Untersuchung konzentriert sich auf den Impulsdruck an der Wand des Tanks, welcher durch erzwungene mehrstufige Schwingungen hervorgerufen wurde. Im vorangegangenen Experiment hat sich gezeigt, dass erzwungene mehrstufige Schwingungen einen stärkeren Impulsdruck im Vergleich mit den einzelnen Schwingungen erzeugen. In dieser Studie wird die numerische Analyse der Teilchenmethode beschrieben, welche auf der Technik der endlichen Inhalte für die Simulation der oben angeführten Erscheinungen basiert. Die vorgeschlagene Teilchenmethode scheint für die Simulation einer nichtlinearen Erscheinung nützlich. Die Autoren vergleichen die berechneten Ergebnisse der zeitlichen Historie des Drucks mit den experimentellen Ergebnissen.

\section{SYMULACJA CHLUPANIA ZBIORNIKA OSCYLUJĄCA DO KILKU STOPNI SWOBODY METODĄ CZĄSTEK}

Zagadnienie uderzenia zbiornika jest bardzo ważne na etapie projektowania statków na LNG/LPG. Problem ten powoduje impulsowe obciążenie struktury statku i często uważany jest za nieliniowy. W celu prawidłowego oszacowania tych obciążeń impulsowych przeprowadzono wiele badań opartych na podejściu zarówno doświadczalnym, jak i numerycznym. W niniejszym badaniu skupiono się na ciśnieniu impulsowym działającym na ścianę zbiornika, wywołanym wymuszonymi kilkustopniowymi oscylacjami. Z poprzedniego doświadczenia wynikało, że wymuszone kilkustopniowe oscylacje powodują większe ciśnienie impulsowe $\mathrm{w}$ porównaniu $\mathrm{z}$ pojedynczymi oscylacjami. W niniejszym opracowaniu opisano analizę numeryczną metodą cząstek opartą na technice skończonej pojemności służącą do symulacji powyżej opisanych zjawisk. Zaproponowana metoda cząstek wydaje się być przydatna do symulowania silnego zjawiska nieliniowego. Autorzy porównują obliczone historyczne wyniki ciśnienia $\mathrm{z}$ wynikami przeprowadzonych doświadczeń. 